\title{
Pääkirjoitus - Ledare
}

\section{Charlotta Wolff}

Uuden, 10. vuosikerran myötä Auraica siirtyy uudelle vuosikymmenelle. Auraicassa avoimen tieteen periaate on vuoden 2019 aikana viety uudelle tasolle, kun lehdessä on otettu käyttöön niin kutsutut DOI-tunnukset, jotka näkyvät ensimmäistä kertaa tässä käsillä olevassa vuosikerrassa. DOI eli Digital Object Identifier on numerotunnus, joka liitetään pysyvästi verkossa ilmestyneeseen aineistoon, jotta tämä olisi helpompi löytää myös ajan päästä. DOI-tunnusten käyttöönotto helpottaa Auraicassa ilmestyneiden tekstien tunnistamista ja niihin viittaamista tulevaisuudessa.

Lukijalle näkyvin muutos uudistetussa Auraicassa on kuitenkin lehden graafinen ulkoasu, jota on päivitetty vastaamaan paremmin verkossa toimivan lehden visuaalisen viestinnän tarpeita. Lehden artikkelien alussa näkyvä ja Anja Karppisen suunnittelema logo on nykyaikainen kumarrus Aurajoen varressa kehittyneelle kirjalliselle kulttuurille. Lehden verkkosivujen päivitetty graafinen ilme kuvastaa puolestaan Turun akatemiatalon arkadeja.

Auraican uutena päätoimittajana haluan kehittää lehteä edelleen moderniksi ja avoimeksi tieteelliseksi julkaisuksi, joka on varteenotettava viestintäkanava niin nuorille kuin etabloituneillekin tutkijoille. Lehden keskeisinä teemoina pysyvät edelleen Turun valistus, Porthan ja hänen ympäristönsä sekä suomalainen aate-, oppi- ja kulttuurihistoria. Käsillä olevan vuosikerran sisältö heijastaa juuri näitä aihepiirejä, sillä tarjolla on niin Turun akatemiassa kirjoitetun dissertaation analyysi kuin Porthania käsittelevä kantaatti sekä pieni makupala 1700-luvun diplomaattista kulttuuria käsittelevästä tuoreesta väitöskirjasta.

I och med den nya, tionde årgången tar sig Auraica till ett nytt decennium. I Auraica har tillämpandet av den öppna vetenskapens princip tagit ytterligare ett kliv framåt under år 2019, då tidskriften tagit i bruk så kallade DOI-identifieringsnummer, som för första gången syns på tidskriftens sidor i denna årgång. DOI eller Digital Object Identifier är en sifferkod som bestående associeras med en viss text så att denna ska vara lättare att hitta också efter en tid. Ibruktagandet av DOI-nummer gör det lättare att identifiera och hänvisa till texter i Auraica också i framtiden. 
För läsaren är den synligaste förändringen i Auraica tidskriftens grafiska utformning, som uppdaterats för att bättre motsvara behoven förknippade med visuell kommunikation på nätet. Logon som syns i början av artiklarna och som planerats av Anja Karppinen är en nutida hyllning till den skriftliga kultur som utvecklats vid Aura stränder. Den nya grafiska utformningen av tidskriftens webbsidor har i sin tur inspirerats av Åbo akademihus arkader.

I egenskap av ny huvudredaktör för Auraica vill jag fortsätta att utveckla tidskriften till en modern och öppen vetenskaplig publikation som är en relevant kommunikationskanal för både unga och mer etablerade forskare. Upplysningen i Åbo, Porthan och hans omgivning samt finländsk idé-, lärdoms- och kulturhistoria kommer också fortsättningsvis att vara centrala teman i tidskriften. Innehållet i den för handen liggande årgången återspeglar just dessa ämnesområden, för vi bjuder på såväl en analys av en dissertation från akademin i Åbo, en kantat över Porthan och ett smakprov på en färsk avhandling om 1700-talets diplomatiska kultur.

Charlotta Wolff

FT, dosentti, Suomen historian ma. professori

Turun yliopisto

charlotta.wolff (apud) utu.fi 